\title{
Grasshopper Abundance in an Arizona Rangeland Undergoing Exurban Development
}

\author{
Carl E. Bock, ${ }^{1}$ Zach F. Jones, ${ }^{2}$ and Jane H. Bock ${ }^{1}$ \\ Authors are ${ }^{1}$ Professors Emeriti, Department of Ecology and Evolutionary Biology, University of Colorado, Boulder, \\ CO 80309-0334; and ${ }^{2}$ Visiting Professor, Biology Department, The Colorado College, Colorado Springs, CO 80903.
}

\begin{abstract}
Housing developments are replacing ranches in the southwestern United States, with potentially significant but little-studied ecological effects. We counted grasshoppers (Orthoptera: Acrididae) and measured vegetative cover for 2 years in a grassland and mesquite/oak savanna in southeastern Arizona, on 48 transects that were grazed by livestock, embedded in low-density housing developments, or both, or neither. Grasshopper species richness was unrelated to grazing or development, but grasshopper abundance was much higher on exurban transects where homeowners kept livestock than in the other areas. Forb canopy and basal area also were highest in grazed exurban areas, perhaps because exurban grazing was relatively patchy, frequently involved horses, and created disturbances more conducive to forb establishment than did relatively uniform grazing on nearby ranches. Abundance patterns of 3 grasshopper subfamilies were generally consistent with their known habitat preferences. Counts of grassfeeding Gomphocerinae were relatively high in ungrazed and unburned areas, and positively correlated with grass cover. Numbers of forb- and mixed-feeding Melanoplinae were positively correlated with forb cover across all transects, and melanoplines dominated counts on grazed exurban properties. Band-winged grasshoppers (Oedipodinae) prefer areas of sparse vegetation, and their numbers were negatively correlated with height of ground vegetation and positively associated with the presence of livestock, in both exurban and undeveloped landscapes. Overall, our results suggest that heterogeneous landscapes in exurban areas that included small livestock pastures had higher grasshopper densities than either ungrazed areas or large cattle ranches.
\end{abstract}

\section{Resumen}

El desarrollo de áreas residenciales esta substituyendo a las áreas de rancho en el sur-oeste de los Estados Unidos, con efectos ecológicos potencialmente significativos pero muy poco estudiados. Hicimos el conteo de saltamontes (orthoptera: Acrididae) y medimos la cobertura vegetal durante 2 años en un prado y sabana de enebro/roble en el sudeste de Arizona, en 48 transectos pastados por ganado, en medio de desarrollos residenciales de baja densidad, o ambos, o ninguno. La riqueza de saltamontes no estaba relacionada al pastoreo o al desarrollo, pero su abundancia fue mucho más alta en transectos exurbanos, donde los dueños de propiedades mantenían ganado, que en otras áreas. El dosel y el área basal de hierbas fueron también más altos en áreas exurbanas pastadas, probablemente porque el pastoreo, frecuentemente hecho por caballos, en áreas exurbanas estaba más parchado, y se crearon perturbaciones más conducentes al establecimiento de hierbas que en áreas de pastoreo uniforme en ranchos próximos. Los patrones de abundancia de 3 subfamilias de saltamontes fueron generalmente consistentes con sus preferencias de hábitat conocidos. Los conteos de alimentación de la subfamilia Gomphocerinae fueron relativamente altos en áreas sin pastoreo y sin quemar, y positivamente correlacionados a la cobertura vegetal. El número de hierbas y la alimentación de la subfamilia Melanoplinae estuvieron positivamente correlacionados con la cobertura de hierbas en todos los transectos y esta subfamilia dominó los conteos en las propiedades exurbanas pastadas. Los saltamontes de la subfamilia Oedipodinae prefieren áreas de vegetación escasa, y su conteo estuvo negativamente correlacionado con la altura de la vegetación y positivamente asociados con la presencia de ganado en paisajes exurbanos y no desarrollados. En general, nuestros resultados sugieren que paisajes heterogéneos en áreas exurbanas que incluyen pequeñas pasturas de ganado tuvieron mayores densidades de saltamontes que las áreas sin pastoreo o grandes ranchos ganaderos.

Key Words: Acrididae, fire, forbs, grassland, grazing, livestock, mesquite, oak

\section{INTRODUCTION}

Throughout much of the American West, ranchlands are being converted into low-density housing developments that are not part of urban centers (Knight et al. 1995). This widespread land use change, termed exurbanization, has profound ecological

Research was supported by the Ecology Program of the National Science Foundation. Correspondence: Carl E. Bock, Ecology and Evolutionary Biology, University of Colorado, Boulder, C0 80309-0334. Email: carl.bock@colorado.edu

Manuscript received 26 January 2006; manuscript accepted 4 September 2006. implications (Theobald 2004; Hansen and Brown 2005). However, the environmental consequences of exurbanization have been relatively little studied compared to other factors influencing the structure and function of rangeland ecosystems (Hansen et al. 2005; but see Maestas et al. 2002, 2003). Potentially negative effects of exurban development include habitat loss, landscape perforation and fragmentation, altered hydrologic and fire regimes, and the introduction and spread of exotics (Brussard et al. 1994). Alternatively, species that are sensitive to the effects of livestock grazing could benefit from exurbanization if the development leaves sufficient natural areas and keeps them free of livestock (Wuerthner 1994). A 
confounding factor in this "cows vs. condos" debate is that many exurbanites keep small numbers of livestock (especially horses) on their "ranchettes" (Maestas et al. 2002; Sengupta and Osgood 2003), such that effects of livestock grazing might equal or exceed those on the former ranches themselves.

Grasshoppers (Orthoptera: Acrididae) are abundant insects in rangeland ecosystems (Otte 1981; Joern and Gaines 1990). Grasshopper populations and community composition are influenced by climate, fire, food supply, and ungulate grazing, and these relationships have been well studied (e.g., Evans 1988; Capinera and Horton 1989; Belovsky and Slade 1995; Joern 2005). Although there has been some work on grasshoppers in urban environments (Nagy 1997; Reinert et al. 2001), we are aware of no studies that have examined the effects of exurban development of former ranchlands on the abundance and variety of grasshoppers, in the Southwest or anywhere else.

Our objective in the present study was to examine the independent and interactive effects of livestock grazing and exurban development on the abundance and variety of grasshoppers in the Sonoita Valley of southeastern Arizona. We chose this study area for 2 reasons. First, some cattle ranches in the valley have been converted to housing developments over the past 30 years, and some but not all of these permit homeowners to keep livestock on their properties (Sonoita Crossroads Community Forum 2002). Second, the valley includes a 3 200-ha undeveloped reserve of the National Audubon Society, the Appleton-Whittell Research Ranch, which has been ungrazed by livestock since 1968 (Bock and Bock 2000), and where prior research has quantified the effects of grazing, fire, and exotic vegetation on the abundance and variety of grasshoppers (Bock et al. 1986; Jepson-Innes and Bock 1989; Bock and Bock 1991). Using the Research Ranch as a control, we counted grasshoppers over a 2-year period in parts of the Sonoita Valley that were in exurban developments, or grazed by livestock, or both, or neither.

\section{METHODS}

\section{Study Area and Experimental Design}

The Sonoita Valley lies at $1300-1600 \mathrm{~m}$ elevation, between the Santa Rita and Huachuca Mountains, in Santa Cruz County, Arizona (lat $31^{\circ} 33-44^{\prime} \mathrm{N}$, long $110^{\circ} 29-42^{\prime} \mathrm{W}$ ). Predominant ground cover consists of perennial bunchgrasses in the genera Bouteloua, Aristida, Eragrostis, and Hilaria, interspersed with scattered low shrubs, succulents, and a large variety of forbs (McLaughlin et al. 2001). Certain parts of the valley are treeless, whereas others are savannas with either scattered mesquite (Prosopis velutina Wooton) or Emory oak (Quercus emoryi Torrey) mixed with Arizona white oak (Quercus arizonica Sarg.). Vegetation of the study area consists largely of native plants, although 2 species of African lovegrasses (Eragrostis spp.) have become locally common in some parts of the valley. Temperatures vary from a mean January daily minimum of $-3.0^{\circ} \mathrm{C}$ to a mean June daily maximum of $32.6^{\circ} \mathrm{C}$ (Bock and Bock 2000). During the period of this study (2003-2004), annual precipitation at the Research Ranch was $76 \%$ of the 26 -year average of $43.6 \mathrm{~cm}$ (L. Kennedy, personal communication, September 2005). At another site in the valley, precipitation was $89 \%$ of the 23-year average of $41.6 \mathrm{~cm}(\mathrm{~J}$. Woods, personal communication, September 2005).

An analysis conducted in 2000 showed that the Sonoita Valley consisted of about $50 \%$ private and $50 \%$ public land, the latter including areas managed by the US Department of Agriculture Forest Service, the US Department of Interior Bureau of Land Management, and the State of Arizona (Sonoita Crossroads Community Forum 2002). Of the private lands, about $77 \%$ were cattle ranches, and the remainder consisted mostly of exurban single family housing developments and small commercial centers in the unincorporated towns of Elgin and Sonoita. Housing density in the exurban developments where we worked averaged about 1 home $\cdot 5.2 \mathrm{ha}^{-1}$.

In the fall of 2002 we established $48200-\mathrm{m}$ transects in the valley, distributed over an area of about $480 \mathrm{~km}^{2}$. The average distance from the midpoint of each transect to that of its nearest neighbor was $750 \mathrm{~m}$ (range: $325-2000 \mathrm{~m}$ ). We set out the transects in a balanced experimental design, with replicates in each of 4 landscape and land use categories: 1) 12 transects evenly divided between 2 undeveloped ranches grazed by cattle and a few horses (the Babacomari and Empire ranches), 2) 12 transects on the undeveloped and ungrazed Research Ranch, 3) 12 transects on 12 different exurban properties whose owners did not keep livestock, and 4) 12 transects on 12 different exurban properties whose owners grazed small numbers of either horses (6 sites), cattle (4 sites), both cattle and horses (1 site), or sheep (1 site). We further balanced our sampling design such that each group of 12 transects included 4 each in open grassland, mesquite savanna, and oak savanna. Landscaping was restricted to the immediate vicinity of homes, so most of the land in the exurban neighborhoods supported natural grassland and savanna vegetation.

Livestock grazing intensities on the 2 cattle ranches were moderate and flexible in response to precipitation and resulting grass production. Stocking density on the Empire Ranch during the period of our study (2003-2004) was about 1 cow-calf unit $\cdot 17 \mathrm{ha}^{-1}$, with no more than $1 \mathrm{mo} \cdot \mathrm{y}^{-1}$ of rotational grazing on any individual pasture, and with the added requirement that no more than $30 \%$ of forage be taken in any year $(\mathrm{M}$. Donaldson, personal communication, September 2005). Grazing on the Babacomari Ranch involved steers or heifers only, brought to the ranch in October weighing about $200 \mathrm{~kg}$ and sold the following September weighing about $340 \mathrm{~kg}$. Stocking density was about 1 animal $12 \mathrm{ha}^{-1}$ on the ranch as a whole during 2003-2004. Grazing was rotational, and limited to 45 $\mathrm{d} \cdot \mathrm{y}^{-1}$ on any individual pasture (D. Ruppel, personal communication, September 2005). We could not calculate meaningful stocking densities on those exurban properties where the owners kept livestock, because nearly all animals relied substantially on supplementary feed. However, data on height of ground vegetation and percentage of grass cover permitted us to compare results of grazing between exurban developments and the 2 cattle ranches (see Results).

A confounding factor in this study was that a large wildfire (the Ryan Fire) burned about $85 \%$ of the Research Ranch in April of 2002, 14 months prior to the start of our fieldwork. Because of the extent and location of this burn, we had to place 8 of the 12 transects on the Research Ranch in areas that had burned in this fire, including 3 of the 4 mesquite transects and 
all 4 of the grassland transects. Two mesquite transects on the Babacomari Ranch also had burned in the Ryan Fire. Exclusion of the 10 burned transects would have compromised our sampling design by altering the balance of habitat replicates among sites that were grazed vs. ungrazed and developed vs. undeveloped. Therefore, we included all the transects in our analyses, but compared and contrasted results from 2003, when fire effects were still evident, with those from 2004, by which time fire effects on vegetative ground cover had largely disappeared (see Results).

\section{Grasshopper Counts}

We counted grasshoppers along the 200-m transects in a repeating sequence, usually 5 or 6 transects per day, such that each transect was counted on 7 different days in 2003 and on 6 different days in 2004, between mid-June and early October of each year. We conducted the counts on clear and relatively calm midmornings (0930-1130 hours). The day before each count we placed $300.5-\mathrm{m}^{2}$ wire hoops at even intervals along each transect. Our method was to count and identify to species (or as nymphs) all individuals flushed from inside each ring, following procedures described in Onsager and Henry (1978). This method is well suited to habitats of generally low-stature vegetation such as occurred in the study area, and we had applied it successfully in previous grasshopper studies in the Sonoita Valley (Bock et al. 1986; Bock and Bock 1991). Our metric for comparison of grasshopper abundance in different landscapes was the mean number of individuals recorded per count per transect (summed for all 30 hoops), for each year separately and for the 2 years averaged together. Grasshopper nomenclature is from Otte $(1981,1984)$ and Pfadt (2002).

\section{Vegetation}

In July-August of 2003 and 2004, we sampled ground vegetation at 400 points spaced at $1-\mathrm{m}$ intervals along $4100-\mathrm{m}$ transects radiating in cardinal compass directions from the midpoint of each of the 48 grasshopper transects. At each point we recorded the following: 1) height of the tallest plant, exclusive of trees, 2) the presence and identity of any plant rooted at that point as a measure of basal area cover, and 3) the presence and identity of any plant whose canopy covered the point. Botanical nomenclature is from McLaughlin et al. (2001). Points without a vegetation canopy were assigned a height of 0 . Shrub and succulent canopy combined averaged only $5 \%$ of points across the 48 sampling locations, and forbs usually were shorter than grasses. Therefore, data on vegetation height primarily reflected the stature of grasses, whose combined canopy across all transects in both years averaged $76 \%$.

\section{Statistical Analyses}

The Research Ranch study site provided an unusual opportunity to measure grasshopper abundance in a sizeable (3 $200 \mathrm{ha}$ ) landscape that was undisturbed by development and longprotected from livestock grazing. However, because all 12 of our undeveloped and ungrazed transects were necessarily confined to this 1 site, they must be considered as pseudoreplicates. Additionally, the 12 grazed and undeveloped transects were divided between 2 large cattle ranches to which we had access. Given the unavoidable pseudoreplication among our undeveloped transects, all statistical inferences must be limited to the particular areas represented by this study (Wester 1992), and they should not be extrapolated to other landscapes.

We applied analysis of variance to grasshopper counts and vegetation data, in order to examine the independent and interactive effects of livestock grazing and exurban development. Grasshopper data were square-root transformed prior to analysis, which reduced heterogeneity of variances among sets of counts (Sokal and Rohlf 1995). As a result, grasshopper and vegetation data met assumptions for analysis of variance (Sokal and Rohlf 1995).

We first explored results of multifactor analysis of variance that included 3 independent variables (habitat, grazing, and exurban development) and 1 repeated measure (year) in a single model. However, we ultimately chose to present and interpret the results of a simpler 2-way approach for 2 reasons. First, although there were significant differences in grasshopper abundances among the 3 habitats (oak savanna, mesquite savanna, and grassland), there were no significant interactions between habitat type and the 2 independent variables of interest in the present study (grazing and development) for counts of grasshoppers as a whole, or for counts of the 3 different grasshopper subfamilies. Second, significant interactions between the repeated measure (year) and the independent variables made it difficult to interpret our overall results. Therefore, for clarity of data presentation and interpretation, we compared the main and interactive effects of livestock grazing and exurban development using 2-way analyses of variance, with the dependent variables being grasshopper and vegetation data for each year separately, and for the 2 years averaged together.

In a second analytical approach, we computed productmoment correlations between square-root transformed grasshopper counts and vegetation measurements across all 48 transects, for each year separately, to look for relationships between grasshopper abundance and habitat characteristics. All statistical tests were performed in Statview 5.0.1 (SAS Publishing 1999), with $P<0.05$ considered significant, and $0.05<P<0.10$ considered marginally significant.

\section{RESULTS}

\section{Grasshopper Species Richness and Abundance}

We identified 41 grasshopper species during this study. Species richness per transect did not differ among treatments (Fig. 1A), but overall numbers were much higher in exurban areas where homeowners kept livestock than in the other landscape categories (Fig. 1B). The result was a significant positive interaction between development and grazing in 2-way analysis of variance of count data averaged across both years of the study $\left(F_{1,44}=7.38, P=0.009\right)$.

Grazing and development effects differed depending on grasshopper subfamily and year (Table 1). Numbers of slantfaced grasshoppers (subfamily Gomphocerinae) were higher in grazed areas in 2003, and unaffected by exurban development, but the grazing effect was only marginally significant statistically (Table 1). Counts of gomphocerines in 2004 were unaffected by grazing or development. The most abundant 

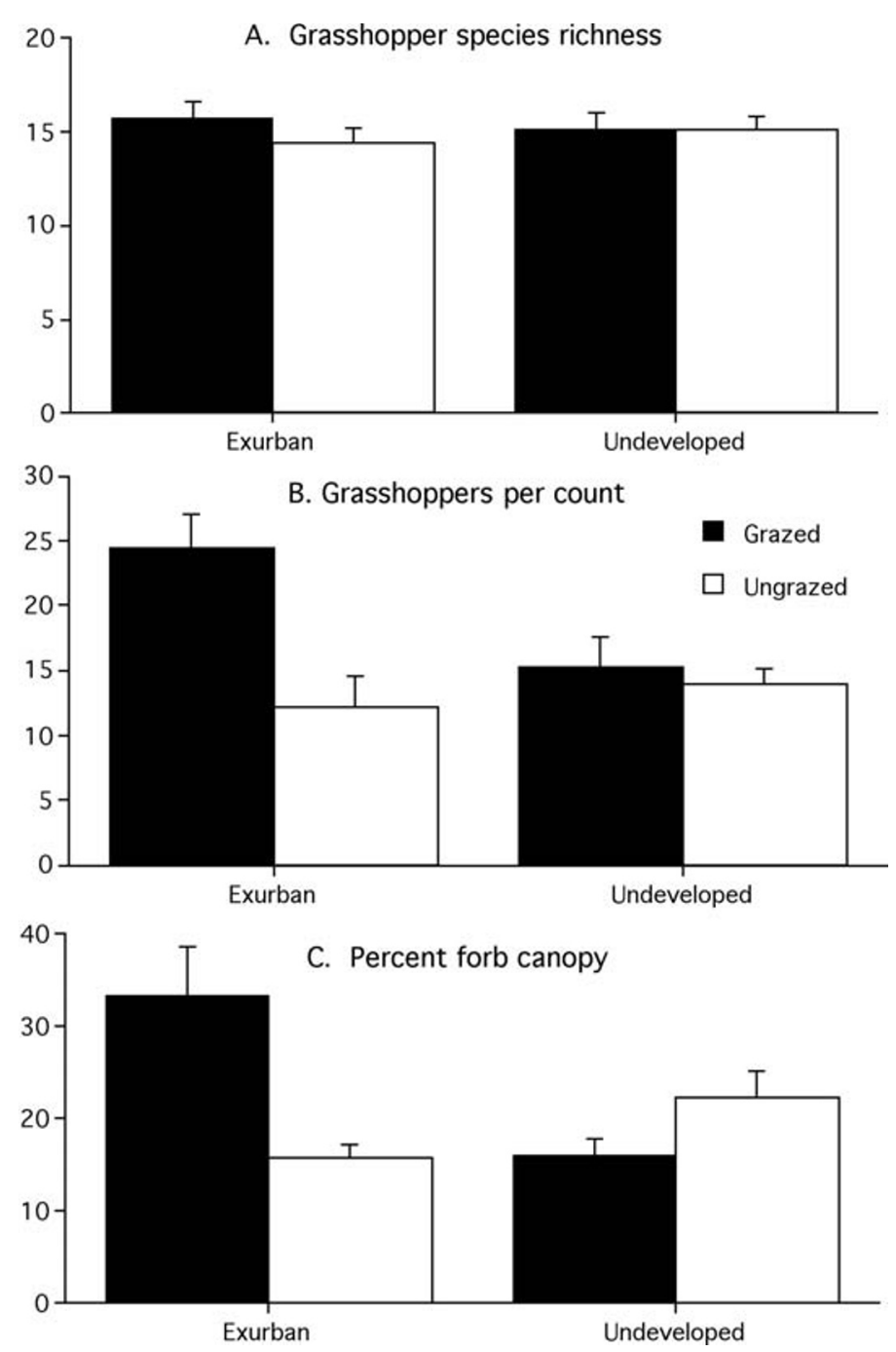

Figure 1. Grasshopper counts and vegetative cover measurements, 2003-2004, from 48 transects in southeastern Arizona that were in exurban vs. undeveloped landscapes, and that were grazed vs. ungrazed by livestock. A, Mean (SE) grasshopper species richness. B, Grasshoppers $\cdot$ count $^{-1}$. C, Percentage of forb canopy.

gomphocerines in our study area were Boopedon nubilum, Boopedon flaviventris, Parapomala wyomingensis, and Eritettix simplex. Spur-throated grasshoppers (subfamily Melanoplinae) were numerically dominant in our study area, especially in exurban areas where homeowners kept livestock and on the ungrazed and undeveloped Research Ranch transects the first year after they had burned (Table 1). The most abundant species were Melanoplus regalis, Melanoplus desultorius, Conalcea humphreysii, and Phoetaliotes nebrascensis. Melanoplines as a group were more abundant on grazed transects in exurban areas than elsewhere in 2003 and again in 2004, resulting in significant positive interactions between grazing and development in both years (Table 1). Numbers of band-winged grasshoppers (subfamily Oedipodinae) were higher in grazed areas in 2004, independent of development. However, the pattern for oedipodines was more complex in 2003. In this year, oedipodines were more abundant on grazed than on ungrazed transects in exurban areas, but showed the opposite trend in undeveloped areas, resulting in a significant interaction between grazing and development (Table 1). The most abundant oedipodines were Arphia pseudonietana, Trimerotropis pallidipennis, Trachyrachis kiowa, and Conozoa carinata.

\section{Vegetation}

The vegetation component showing the most similar pattern to the 2-year average of total grasshopper abundance was forb canopy (Fig. 1C), for which there also was a significant positive interaction between grazing and development $\left(F_{1,44}=14.26\right.$, $P=0.0005)$. Forb canopy and forb basal area also were highest along transects that were grazed and in exurban neighborhoods in each year separately (Table 2). The most abundant forbs in the study area were all native, but most were species that colonized disturbed sites, including Amaranthus palmeri S. Watson, Ambrosia confertifolia DC, Calliandra eriophylla Bentham, Chamaesyce hirta (L.) Millsp., Drymaria molluginea (Lag.) Didr., Poinsetta spp., Sida abutifolia P. Mill, Viguiera annua (Jones) Blake, and Viguiera dentata (Cav.) Spreng.

In 2003, ground vegetation was tallest on ungrazed exurban transects and shortest on ungrazed transects in undeveloped areas (Table 2), a pattern that likely reflected residual negative effects of the 2002 fire on 8 of 12 transects on the Research Ranch, and which resulted in a significant interaction between grazing and development. By contrast, ground cover in 2004 was taller in ungrazed areas independent of development (Table 2).

A relatively low percentage of grass canopy on the recently burned ungrazed and undeveloped transects in 2003 resulted in a significant interaction between grazing and development in that year, because grass canopy was greater on ungrazed transects in developed landscapes (Table 2). However, by 2004 grass canopy was marginally higher on ungrazed than on grazed transects as a whole, independent of development. Grass basal area also was relatively low on the ungrazed and undeveloped Research Ranch transects in 2003, but in 2004 grass basal area was highest on the Research Ranch, resulting in a significant negative grazing effect and marginally significant negative exurban effect in the second year of the study (Table 2). Canopy cover of exotic lovegrasses averaged $<5 \%$ across all 48 sites, and there were no differences among treatments. The most abundant native grasses were blue grama (Boutelous gracilis [Willd. ex Kunth] Lag. ex Griffiths), sideoats grama (B. curtipendula [Michx.] Torrey), curly mesquite (Hilaria belangeri [Steud.] Nash), and a variety of three-awns (Aristida spp.).

\section{Correlations Between Grasshoppers and Vegetation}

Counts of grasshoppers in the 3 subfamilies were weakly but significantly correlated with different sets of vegetation measurements (Table 3). Numbers of Gomphocerinae were positively correlated with grass basal area in both years, marginally positively correlated with grass canopy in 2004, and unrelated to forb cover or height of the tallest plant in either year. Melanopline numbers were positively correlated with forb canopy and forb basal area in both years, but unrelated to grass cover or plant height (Table 3). Counts of Oedipodinae were negatively correlated with height of the tallest plant in 
Table 1. Mean (SE) count per subfamily per year, subfamily counts as percentages of total counts of all grasshoppers combined, and results of 2way analyses of variance comparing abundances per count for 3 grasshopper subfamilies on 200-m transects that were grazed vs. ungrazed, and exurban vs. undeveloped, in the Sonoita Valley of southeastern Arizona in 2003 and 2004 ( $n=12$ transects $\cdot \mathrm{yr}^{-1}$ in each landscape category).

\begin{tabular}{|c|c|c|c|c|c|c|c|c|}
\hline \multirow[b]{2}{*}{ Subfamily $\cdot \mathrm{yr}^{-1}$} & \multirow[b]{2}{*}{ Variable } & \multicolumn{2}{|c|}{ Exurban } & \multicolumn{2}{|c|}{ Undeveloped } & \multicolumn{3}{|c|}{$F(P)$ for different effects ${ }^{1}$} \\
\hline & & Grazed & Ungrazed & Grazed & Ungrazed & Grazing & Exurbanization & Interaction \\
\hline \multicolumn{9}{|l|}{ Gomphocerinae } \\
\hline \multirow[t]{2}{*}{2003} & Mean count (SE) & 7.07 (1.89) & $5.81(2.55)$ & $9.00(2.20)$ & $3.68(0.98)$ & $3.62(0.061)$ & $0.07(\mathrm{~ns})^{2}$ & 0.74 (ns) \\
\hline & Percentage of total & 33.2 & 43.2 & 51.3 & 24.8 & & & \\
\hline \multirow[t]{2}{*}{2004} & Mean count (SE) & $3.65(1.15)$ & $2.40(0.57)$ & $3.65(1.21)$ & $5.01(1.26)$ & $0.12(\mathrm{~ns})$ & 1.24 (ns) & $1.43(\mathrm{~ns})$ \\
\hline & Percentage of total & 13.2 & 21.7 & 27.8 & 38.4 & & & \\
\hline \multicolumn{9}{|l|}{ Melanoplinae } \\
\hline \multirow[t]{2}{*}{2003} & Mean count (SE) & $12.77(1.91)$ & $7.03(1.62)$ & $7.55(1.19)$ & $9.76(0.86)$ & 1.38 (ns) & 0.16 (ns) & $9.20(0.004)$ \\
\hline & Percentage of total & 60.0 & 52.3 & 43.1 & 65.9 & & & \\
\hline \multirow[t]{2}{*}{2004} & Mean count (SE) & $21.76(3.34)$ & $7.79(1.58)$ & $7.57(1.58)$ & $6.90(1.07)$ & $10.62(0.002)$ & $12.03(0.001)$ & $9.83(0.003)$ \\
\hline & Percentage of total & 78.6 & 70.3 & 57.7 & 52.9 & & & \\
\hline \multicolumn{9}{|l|}{ Oedipodinae } \\
\hline \multirow[t]{2}{*}{2003} & Mean count (SE) & $1.43(0.27)$ & $0.60(0.14)$ & $0.98(0.25)$ & $1.37(0.27)$ & 0.35 (ns) & 0.05 (ns) & $6.03(0.018)$ \\
\hline & Percentage of total & 6.7 & 4.5 & 5.6 & 9.3 & & & \\
\hline \multirow[t]{2}{*}{2004} & Mean count (SE) & $2.28(0.35)$ & $0.88(0.16)$ & $1.89(0.41)$ & $1.13(0.22)$ & $12.27(0.001)$ & $0.03(\mathrm{~ns})$ & 1.53 (ns) \\
\hline & Percentage of total & 8.2 & 7.9 & 14.4 & 8.7 & & & \\
\hline
\end{tabular}

${ }^{1} \mathrm{df}=1,1,1,44$ for each analysis of variance; data were square-root transformed prior to analysis.

${ }^{2}$ ns indicates not statistically significant $(P>0.10)$.

both years, positively correlated with forb canopy and basal area cover in 2003, and marginally positively correlated with forb basal area in 2004 .

\section{DISCUSSION}

Results of this study suggest that livestock grazing on small pastures associated with exurban developments can result in grasshopper densities that are much higher than those on either cattle ranches or ungrazed areas. However, the gener- ality of this pattern must be determined by additional studies in other areas, given the fact that our study involved pseudoreplicated plots in just 1 valley in southeastern Arizona (Wester 1992).

In the Sonoita Valley in 2003-2004, livestock grazing affected vegetation similarly on cattle ranches and in exurban developments, in terms of height of ground cover, grass canopy, and grass basal area. However, grazing in exurban areas resulted in much higher cover of forbs than it did in undeveloped areas. Although we have no direct evidence of the causes of this pattern, likely factors resulting in increased forb

Table 2. Mean (SE) and results of 2-way analyses of variance comparing vegetative cover on 200-m transects that were grazed vs. ungrazed, and

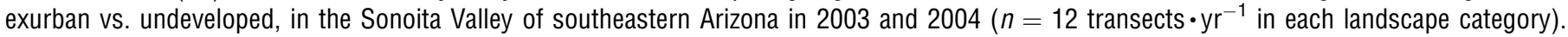

\begin{tabular}{|c|c|c|c|c|c|c|c|c|}
\hline \multirow[b]{3}{*}{ Vegetation variable } & \multirow[b]{3}{*}{ Year } & \multicolumn{4}{|c|}{ Mean (SE) } & & & \\
\hline & & \multicolumn{2}{|c|}{ Exurban } & \multicolumn{2}{|c|}{ Undeveloped } & \multicolumn{3}{|c|}{$F(P)$ for different effects ${ }^{1}$} \\
\hline & & Grazed & Ungrazed & Grazed & Ungrazed & Grazing & Exurbanization & Interaction \\
\hline \multirow[t]{2}{*}{ Height (cm) } & 2003 & $17.25(1.55)$ & $24.22(2.48)$ & $18.55(2.05)$ & $14.08(1.92)$ & $0.37(\mathrm{~ns})^{2}$ & $4.79(0.033)$ & $8.02(0.007)$ \\
\hline & 2004 & $13.66(1.65)$ & $23.37(1.89)$ & $15.49(1.83)$ & $25.19(1.89)$ & $25.70(0.001)$ & $1.65(\mathrm{~ns})$ & $0.08(\mathrm{~ns})$ \\
\hline \multirow[t]{2}{*}{ Grass canopy (\%) } & 2003 & $75.35(5.66)$ & $85.04(7.41)$ & $78.21(4.27)$ & $60.40(3.86)$ & $0.31(\mathrm{~ns})$ & $3.26(0.078)$ & $7.24(0.010)$ \\
\hline & 2004 & $72.71(4.14)$ & $81.90(6.19)$ & $76.31(2.85)$ & $81.23(2.28)$ & $2.89(0.096)$ & $0.13(\mathrm{~ns})$ & $0.27(\mathrm{~ns})$ \\
\hline \multirow[t]{2}{*}{ Grass basal area (\%) } & 2003 & $12.81(1.70)$ & $15.06(1.63)$ & $15.23(1.41)$ & $12.35(1.28)$ & $0.04(\mathrm{~ns})$ & $0.01(\mathrm{~ns})$ & $2.87(0.097)$ \\
\hline & 2004 & $17.21(1.47)$ & $20.06(1.67)$ & $18.58(1.37)$ & $25.04(1.80)$ & $8.59(0.005)$ & $4.03(0.051)$ & $1.29(\mathrm{~ns})$ \\
\hline \multirow[t]{2}{*}{ Forb canopy (\%) } & 2003 & $48.27(7.55)$ & $21.73(2.27)$ & $24.23(2.81)$ & $31.33(4.03)$ & $4.38(0.042)$ & $2.42(\mathrm{~ns})$ & $13.11(0.001)$ \\
\hline & 2004 & $18.56(3.12)$ & $9.85(1.48)$ & $7.73(1.56)$ & $13.13(2.09)$ & $0.59(\mathrm{~ns})$ & $3.06(0.087)$ & $10.65(0.002)$ \\
\hline \multirow[t]{2}{*}{ Forb basal area (\%) } & 2003 & $5.40(0.89)$ & $2.19(0.30)$ & $2.83(0.46)$ & $4.42(0.77)$ & $1.56(\mathrm{~ns})$ & $0.07(\mathrm{~ns})$ & $13.61(0.001)$ \\
\hline & 2004 & $3.23(0.77)$ & $1.25(0.23)$ & $1.52(0.44)$ & $1.50(0.30)$ & $4.28(0.045)$ & $2.28(\mathrm{~ns})$ & $4.10(0.049)$ \\
\hline
\end{tabular}

${ }^{1} \mathrm{df}=1,1,1,44$ for each analysis of variance.

${ }^{2}$ ns indicates not statistically significant $(P>0.10)$. 
Table 3. Product-moment correlations (and $P$ values) between the square-root of counts of grasshoppers and various aspects of vegetative cover on 48 200-m transects in the Sonoita Valley of southeastern Arizona.

\begin{tabular}{|c|c|c|c|c|c|c|}
\hline \multirow[b]{3}{*}{ Vegetation variable } & \multicolumn{6}{|c|}{ Grasshopper subfamily and year } \\
\hline & \multicolumn{2}{|c|}{ Gomphocerinae } & \multicolumn{2}{|c|}{ Melanoplinae } & \multicolumn{2}{|c|}{ Oedipodinae } \\
\hline & 2003 & 2004 & 2003 & 2004 & 2003 & 2004 \\
\hline Height & $-0.18(\mathrm{~ns})^{1}$ & $-0.16(\mathrm{~ns})$ & $-0.20(\mathrm{~ns})$ & $-0.19(\mathrm{~ns})$ & $-0.32(0.027)$ & $-0.55(0.001)$ \\
\hline Grass canopy (\%) & $0.23(\mathrm{~ns})$ & $0.26(0.071)$ & 0.05 (ns) & 0.17 (ns) & $-0.08(\mathrm{~ns})$ & $-0.10(\mathrm{~ns})$ \\
\hline Grass basal area (\%) & $0.35(0.014)$ & $0.48(0.001)$ & $0.04(\mathrm{~ns})$ & $-0.04(\mathrm{~ns})$ & $0.01(\mathrm{~ns})$ & $-0.03(\mathrm{~ns})$ \\
\hline Forb canopy (\%) & 0.12 (ns) & $0.12(\mathrm{~ns})$ & $0.30(0.036)$ & $0.32(0.026)$ & $0.29(0.046)$ & 0.09 (ns) \\
\hline Forb basal area (\%) & $0.16(\mathrm{~ns})$ & 0.17 (ns) & $0.26(0.080)$ & $0.30(0.041)$ & $0.41(0.004)$ & $0.25(0.090)$ \\
\hline
\end{tabular}

${ }^{1}$ ns indicates not statistically significant $(P>0.10)$.

cover included the following: 1) episodes of patchy but locally intense grazing on exurban properties, especially by horses that often were enclosed in small areas (Beever and Brussard 2000, Cole et al. 2004) and 2) increased numbers of roads and trails and amounts of bare soil around home sites that may have provided colonization points for weedy plants. By contrast, the cattle ranches we studied were managed to avoid heavy grazing, resulting in stands of grass that were relatively uniform both spatially and temporally, and forb canopies that were comparable to ungrazed sites.

Other vegetation differences among our study sites are attributable to the wildfire that burned 8 of 12 sampling transects on the ungrazed and undeveloped Research Ranch in April of 2002. Specifically, height of ground cover, grass canopy, and grass basal area all were reduced on Research Ranch transects in 2003, but had recovered to levels at or above those on ungrazed exurban transects by 2004. Forb canopy and forb basal area were higher on Research Ranch transects than on their ungrazed exurban counterparts, at least through 2003. These results are consistent with those of previous studies of the effects of fire on grasslands of the Sonoita Valley and elsewhere in the Southwest, which include temporary reductions in grass cover coupled with increases in the abundance and variety of forbs (Bock and Bock 1992; McPherson 1995).

Abundance patterns of grasshopper subfamilies differed among years (Table 1), but they were generally consistent with what is known about their particular food and habitat preferences in the Sonoita Valley and elsewhere (Joern 1979, 1982; Jepson-Innes and Bock 1989; Kemp et al. 1990). Most slant-faced grasshoppers (Gomphocerinae) are grass-feeders (Otte 1981; Pfadt 2002). They neither selected nor avoided grazed transects in the present study, but their numbers were positively correlated with grass basal area across all 48 transects. Gomphocerines were scarce on the undeveloped and ungrazed burned transects in 2003, in terms of both absolute abundance and percent composition of total counts, at a time when these areas had relatively sparse and short grass cover. Slant-faced grasshoppers similarly declined for 2 years following a wildfire on the Research Ranch in 1987 (Bock and Bock 1991).

Spur-throated grasshoppers (subfamily Melanoplinae) have variable diets, often including a high percentage of forbs, and they are known to reach high densities in disturbed sites with high forb cover (Evans 1988; Craig et al. 1999; Pfadt 2002;
Russell and Detling 2003). Our results are entirely consistent the findings of these earlier studies, because melanoplines numerically dominated our counts overall and were particularly abundant in 2 landscapes with high forb cover-on grazed exurban transects as well as on ungrazed and undeveloped transects on the Research Ranch in the first year after the fire (Table 1). These were the same areas with the highest forb basal areas (Table 2). One melanopline, Phoetaliotes nebrascensis, is noteworthy because it was the most abundant species on our grazed exurban transects, although it has been found elsewhere to feed primarily on grasses (Evans 1988). We did not conduct gut analyses in the present study. However, other researchers have documented that forbs can compose at least part of the diet of Phoetaliotes (Joern 1979; Quinn and Walgenbach 1990). Furthermore, Jepson (1985) found that although Phoetaliotes mostly ate grasses in ungrazed areas of the Sonoita Valley, it switched to a diet dominated by weedy forbs in heavily grazed sites. We found very high local concentrations of Phoetaliotes in exurban grazed landscapes in the present study, especially in areas with heterogeneous mixtures of weedy forbs and nearby patches of taller grasses.

Band-winged grasshoppers (subfamily Oedipodinae) usually are abundant only in areas with relatively sparse ground cover (Otte 1984). In the present study they were most common in areas where livestock grazing or fire had reduced the height of ground vegetation. Their numbers also were correlated positively with forb cover (especially basal area), at least in 2003. However, unlike melanoplines, oedipodines were little if any more abundant in exurban than in undeveloped grazed areas, suggesting that overall height of ground vegetation was the key habitat variable for this group.

Several exurban landowners reported to us that grasshoppers had done significant damage to their vegetable and ornamental flower gardens. Most cases involved sites where homeowners kept livestock on their properties, or where grazing occurred nearby. Although we did not collect grasshopper abundance data in landscaped areas, gardens around homes almost certainly provided additional resources for grasshoppers in the exurban parts of our study area, especially during dry seasons when native green vegetation was sparse (Reinert et al. 2001). Our results suggest that the landscape most likely to host high grasshopper densities was one that included both irrigated gardens and nearby grazed areas with abundant forbs. 


\section{MANAGEMENT IMPLICATIONS}

Grasshoppers can have both ecological and economic significance when they reach high densities in rangeland ecosystems (Otte 1981; Lockwood et al. 2000). Conditions favorable to these herbivorous insects include a spatial mixture of green vegetation for food and cover, and dry sunny bare ground for oviposition (Capinera and Horton 1989; Joern and Gaines 1990; O’Neill et al. 2003). Results of the present study suggest that livestock in exurban neighborhoods created conditions more favorable for grasshoppers than did cattle on large ranches. In our study area, small exurban livestock pastures frequently were nearly devoid of grass, with scattered forbs and much bare ground, whereas adjacent areas, often on the same property, included relatively lush vegetation. These environmental mosaics apparently favored grasshoppers more than the relatively uniform grasslands on the well-managed cattle ranches that we studied, because we found grasshopper densities were much higher in grazed exurban areas than on cattle ranches. If our results are typical, property owners and homeowners associations hoping to avoid grasshopper outbreaks would do well to seek the advice of local ranchers and land managers when designing and implementing land use plans for their neighborhoods, in terms of the sizes, stocking rates, and spatial arrangements of pastures.

\section{ACKNOWLEDGMENTS}

We thank M. and J. Donaldson, K. Simms, S. McFarlin, and the Bureau of Land Management for hosting our work on the Empire Ranch, and D. Ruppel, B. Brophy, and A. and S. Gibson for granting access to the Babacomari Ranch. L. Kennedy, B. Branan, and B. Appleton made available the lands and facilities of the Appleton-Whittell Research Ranch. We are grateful to the following individuals for permitting us to work on their individual properties in exurbanized parts of the Sonoita Valley: M. Bartol, D. and H. Beal, J. Church, S. and J. Clark, B. and N. Cook, S. Dinham, J. and B. Donaldson, M. and B. Donaldson, M. Douglas, J. and E. Dowling, B. and G. Eifrig, S. Franklin, T. and C. Hanson, P. and F. Hoffman, M. Johnson, J. Kolbe, V. and J. Michael, D. Reilly, S. Shields, G. Sill, S. and K. Strom, D. Sturges, L. Wilkening, J. Woods, and P. and K. Workizer. We thank the following individuals for field assistance: B. Audsley, K. Bishop, T. Crook, D. Goodheim, L. Jones, L. Kennedy, B. Loomis, J. MacAdam, A. Marshall, L. Schevets, C. Venot, and C. Wonkka.

\section{LITERATURE CITED}

Belovsky, G. E., and J. B. Slade. 1995. Dynamics of two Montana grasshopper populations-relationships among weather, food abundance and intraspecific competition. Oecologia 101:383-396.

Beever, E. A., and P. F. Brussard. 2000. Examining ecological consequences of feral horse grazing using exclosures. Western North American Naturalist 60:236-254.

Bock, C. E., AND J. H. Bock. 1991. Response of grasshoppers (Orthoptera: Acrididae) to wildfire in a southeastern Arizona grassland. American Midland Naturalist 125:162-167.

Bock, C. E., AND J. H. Bock. 2000. The view from Bald Hill: Thirty years in an Arizona grassland. Berkeley, CA: University of California Press. $197 \mathrm{p}$.

Bock, C. E., J. H. Bock, K. L. JePson, AND J. C. ORTEGA. 1986. Ecological effects of planting African lovegrasses in Arizona. National Geographic Research 2: 456-463.

Bock, J. H., AND C. E. Bock. 1992. Vegetation responses to wildfire in native vs. exotic Arizona grassland. Journal of Vegetation Science 3:439-446.
Brussard, P. F., D. D. Murphy, and C. R. Tracy. 1994. Cattle and conservation biology -another view. Conservation Biology 8:919-921.

Capinera, J. L., and D. R. Horton. 1989. Geographic variation in effects of weather on grasshopper infestation. Environmental Entomology 18:8-14.

Cole, D. N., J. W. Van Wagtendonk, M. P. McClaran, P. E. Moore, and N. K. McDougald. 2004. Response of mountain meadows to grazing by recreational pack stock. Journal of Range Management 57:153-160.

Craig, D. P., C. E. Bock, B. C. Bennett, and J. H. Bock. 1999. Habitat relationships among grasshoppers (Orthoptera: Acrididae) at the western limit of the Great Plains in Colorado. American Midland Naturalist 142:314327.

Evans, E. W. 1988. Grasshopper (Insecta, Orthoptera, Acrididae) assemblages of tallgrass prairie: influences of fire frequency, topography, and vegetation. Canadian Journal of Zoology 66:1495-1501.

Hansen, A. J., AND D. G. Brown. 2005. Land-use change in rural America: rates, drivers, and consequences. Ecological Applications 15:1849-1850.

Hansen, A. J., R. L. Knight, J. M. Marzluff, S. Powell, K. Brown, P. H. Gude, and K. JoNES. 2005. Effects of exurban development on biodiversity: patterns, mechanisms, and research needs. Ecological Applications 15:1893-1905.

JEPSON, K. A. 1985. Response of grasshoppers to changes in vegetation structure and availability: a comparison of grazed and ungrazed sites in southeastern Arizona [M. A. thesis]. Boulder, C0: University of Colorado. $54 \mathrm{p}$.

JePSON-INNES, K., AND C. E. Bock. 1989. Response of grasshoppers (Orthoptera: Acrididae) to livestock grazing in southeastern Arizona: differences between seasons and subfamilies. Oecologia 78:430-431.

JoERN, A. 1979. Feeding patterns in grasshoppers (Orthoptera: Acrididae): factors influencing diet specialization. Oecologia 38:325-347.

JoERN, A. 1982. Vegetation structure and microhabitat selection in grasshoppers (Orthoptera: Acrididae). Southwestern Naturalist 27:197-209.

JoERN, A. 2005. Disturbance by fire frequency and bison grazing modulate grasshopper assemblages in tallgrass prairie. Ecology 86:861-873.

Joern, A., AND S. B. Gaines. 1990. Population dynamics and regulation in grasshoppers. In: R. F. Chapman and A. Joern [EDS.]. Biology of grasshoppers. New York, NY: John Wiley and Sons, p 415-482.

Knight, R. L., G. N. Wallace, and W. E. Riebsame. 1995. Ranching the view: subdivisions versus agriculture. Conservation Biology 9:459-461.

Kemp, W. P., S. J. Harvey, and K. M. O'Neill. 1990. Patterns of vegetation and grasshopper community composition. Oecologia 83:299-308.

Lockwood, J. A., A. V. Latchininsky, and M. G. Sergeev [eds.] 2000. Grasshoppers and grassland health: Managing grasshopper outbreaks without risking environmental disaster. Boston, MA: Kluwer Academic Publishers. 221 p.

Maestas, J. D., R. L. Knight, and W. C. Gilgert. 2002. Cows, condos, or neither: what's best for rangeland ecosystems? Rangelands 24:36-42.

Maestas, J. D., R. L. KNIGHt, And W. C. GILGeRt. 2003. Biodiversity across a rural land-use gradient. Conservation Biology 17:1425-1434.

Mclaughion, S. P., E. L. Geiger, and J. E. Bowers. 2001. Flora of the AppletonWhittell Research Ranch, northeastern Santa Cruz County, Arizona. Journal of the Arizona-Nevada Academy of Science 33:113-131.

McPherson, G. R. 1995. The role of fire in desert grasslands. In: M. P. McClaran and T. R. Van Devender [EDS.]. The desert grassland. Tucson, AZ: University of Arizona Press. 130-151.

NAGY, B. 1997. Orthoptera species and assemblages in the main habitat types of some urban areas in the Carpathian Basin. Biologia 52:233-240.

O'Neill, K. M., B. E. Olson, M. G. Rolston, R. Wallander, D. P. Larson, and C. E. SEIBERT. 2003. Effects of livestock grazing on rangeland grasshopper (Orthoptera: Acrididae) abundance. Agriculture Ecosystems and Environment 97:51-64.

Onsager, J. A., And J. E. Henry. 1978. A method for estimating the density of rangeland grasshoppers (Orthoptera: Acrididae) in experimental plots. Acrida 6:429-431.

OTTE, D. 1981. The North American grasshoppers. Volume I (Acrididae: Gomphocerinae and Acridinae). Cambridge, MA: Harvard University Press. $275 \mathrm{p}$.

OTTE, D. 1984. The North American grasshoppers. Volume II (Acrididae: Oedipodinae). Cambridge, MA: Harvard University Press. 366 p. 
Pfadt, R. E. 2002. Field guide to common western grasshoppers. 3rd ed. Laramie, WY: Wyoming Agricultural Experiment Station, Bulletin 912. 41 p.

Quinn, M. A., AND D. D. WalgenBaCh. 1990. Influence of grazing history on the community structure of grasshoppers in a mixed-grass prairie. Environmental Entomology 19:1756-1766.

Reinert, J. A., W. A. Mackay, S. W. George, J. Read, M. C. Engelke, and S. J. Maranz. 2001. Residual chemical control for Melanoplus differentialis (Orthoptera: Acrididae) in urban landscapes. Florida Entomologist 84:380-384.

Russell, R. E., and J. K. Detuing. 2003. Grasshoppers (Orthoptera: Acrididae) and black-tailed prairie dogs (Sciuridae: Cynomys ludovicianus (Ord)): associations between two rangeland herbivores. Journal of the Kansas Entomological Society 76:578-587.

SAS Publishing. 1999. Statview 5.0.1. Cary, NC: SAS Institute. 528 p.
Sengupta, S., and D. E. Osgood. 2003. The value of remoteness: a hedonic estimation of ranchette prices. Ecological Economics 44:91-103.

SokaL, R. R., and F. J. Rohlf. 1995. Biometry. New York, NY: W. H. Freeman and Co. 859 p.

Sonoita Crossroads Community Forum. 2002. A comprehensive plan for northeast Santa Cruz County, Arizona. Available from the Sonoita Crossroads Community Forum, PO Box 1274, Sonoita, AZ.

TheOBALD, D. M. 2004. Placing exurban land-use change in a human modification framework. Frontiers in Ecology and the Environment 2:139-144.

WESTER, D. B. 1992. Viewpoint: replication, randomization, and statistics in range research. Journal of Range Management 45:285-290.

WuerthneR, G. 1994. Subdivisions versus agriculture. Conservation Biology 8:905-908. 